\title{
Miastenija kaip vienas iš paraneoplazinių neurologinių sindromų, susijusių su smulkialąsteliniu plaučių vėžiu. Klinikinis atvejis
}

\author{
R. Bunevičiūtè* \\ R. Masaitienë* \\ A. Klimašauskienë** \\ *Vilniaus universiteto ligoninès \\ Santaros kliniku \\ Neurologijos centras \\ **Vilniaus universitetas, \\ Medicinos fakultetas, \\ Vilniaus universiteto ligoninès \\ Santaros kliniku \\ Neurologijos centras
}

\begin{abstract}
Santrauka. Miastenija, asocijuota su ne užkrūčio liaukos onkologiniais susirgimais, yra retai nustatoma patologija. Šiame straipsnyje pristatysime klinikini atveji, kai buvo histologiškai nustatyta smulkių ląstelių plaučių karcinoma, susijusi su 3 skirtingais paraneoplaziniais neurologiniais sindromais: sensomotorine polineuropatija, limbiniu encefalitu ir seronegatyvia miastenija, patvirtinta ritminès nervo stimuliacijos tyrimo metu.

Priežastinis ryšys tarp miastenijos, kaip paraneoplazinio sindromo, sukelto smulkių ląstelių plaučių karcinomos, iki šiol nèra oficialiai patvirtintas. Tačiau literatūroje vis daugèja įrodymų, kad miastenija galètų būti susijusi ne tik su užkrūčio liaukos, bet ir su kitų lokalizacijų onkologiniais procesais.
\end{abstract}

Raktažodžiai: paraneoplazinis sindromas, miasteninis sindromas, plaučių karcinoma.

\section{IVADAS}

Paraneoplaziniai neurologiniai sindromai (PNS) - su onkologinėmis ligomis susijusi heterogeninè neurologiniu susirgimų grupè, kuri nèra sukelta tiesioginès vėžio invazijos, metastazių ar susijusi su gydymo priešvėžiniais preparatais pasekmèmis [1].

Ši patologija gali paliesti bet kurią nervų sistemos sritį: nuo smegenų žievès iki neuroraumeninès jungties. İvairių paraneoplazinių neurologinių susirgimų dažnis ir pasireiškimas varijuoja ir priklauso nuo onkologinès ligos tipo. Vienas ar daugiau PNS pasireiškia 3-9 \% pacientų, sergančiu smulkių ląstelių plaučiu karcinoma (SLPK), 15-20 \% sergančių timoma ir 3-10\% pacientų, kuriems nustatyti B limfocitų piktybiniai susirgimai $[1,2]$. Visų kitų onkologinių susirgimų atvejais PNS nustatomas vos $1 \%$ pacientu [2].

Nors ir etiopatogenetiniai PNS veiksniai nèra iki galo išaiškinti, manoma, kad imunologiniai mechanizmai yra

\section{Adresas:}

Ramunè Bunevičiūtè

El. paštas ramune.buneviciute@gmail.com viena iš pagrindinių šių susirgimų atsiradimo priežasčių. Antikūnų, nukreiptų prieš nervų sistemos antigenus, įtaka yra pastebėta etiopatogenetinių PNS tyrimų metu [3-5]. Antineuroniniai antikūnai, susiję su PNS, skirstomi ị dvi grupes. Vienai grupei priklauso antikūnai, nukreipti prieš intraląstelinius neuronų baltymus (dar vadinami paraneoplaziniais ar onkoneuroniniais, pvz., anti-Hu, anti-Ri). Jų nustatymas beveik visada rodo onkologinị procesą organizme. Antrajai grupei priklauso antikūnai, nukreipti prieš neuronų paviršiaus ir sinapsès baltymus, pvz., N-metil-Daspartato (NMDA) receptorius. Šie antikūnai aptinkami tiek onkologinių ligų metu, tiek idiopatinių, autoimuninių susirgimų atvejais [6]. Tačiau antineuroninių antikūnų nustatymas nebūtinai patvirtina PNS diagnozę, kaip ir jų nebuvimas neatmeta šios ligos galimybès [7].

Gerėjant paraneoplazinių sindromų diagnostikai ir plečiantis gydymo galimybėms, ši patologija tampa vis aktualesné šiandienejje medicinos praktikoje.

Toliau straipsnyje pristatysime klinikini atveji, kai smulkių ląstelių plaučių karcinoma buvo asocijuota su išplitusiu paraneoplaziniu nervų sistemos pažeidimu, kuris manifestavo miastenijai būdingais simptomais.

(C) Neurologijos seminarai, 2018. Open Access. This article is distributed under the terms of the Creative Commons Attribution 4.0 International License CC-BY 4.0 (http://creativecommons.org/licenses/by/4.0/), which permits unrestricted use, distribution, and reproduction in any medium, provided you give appropriate credit to the original author(s) and the source, provide a link to the Creative Commons license, and indicate if changes were made. 


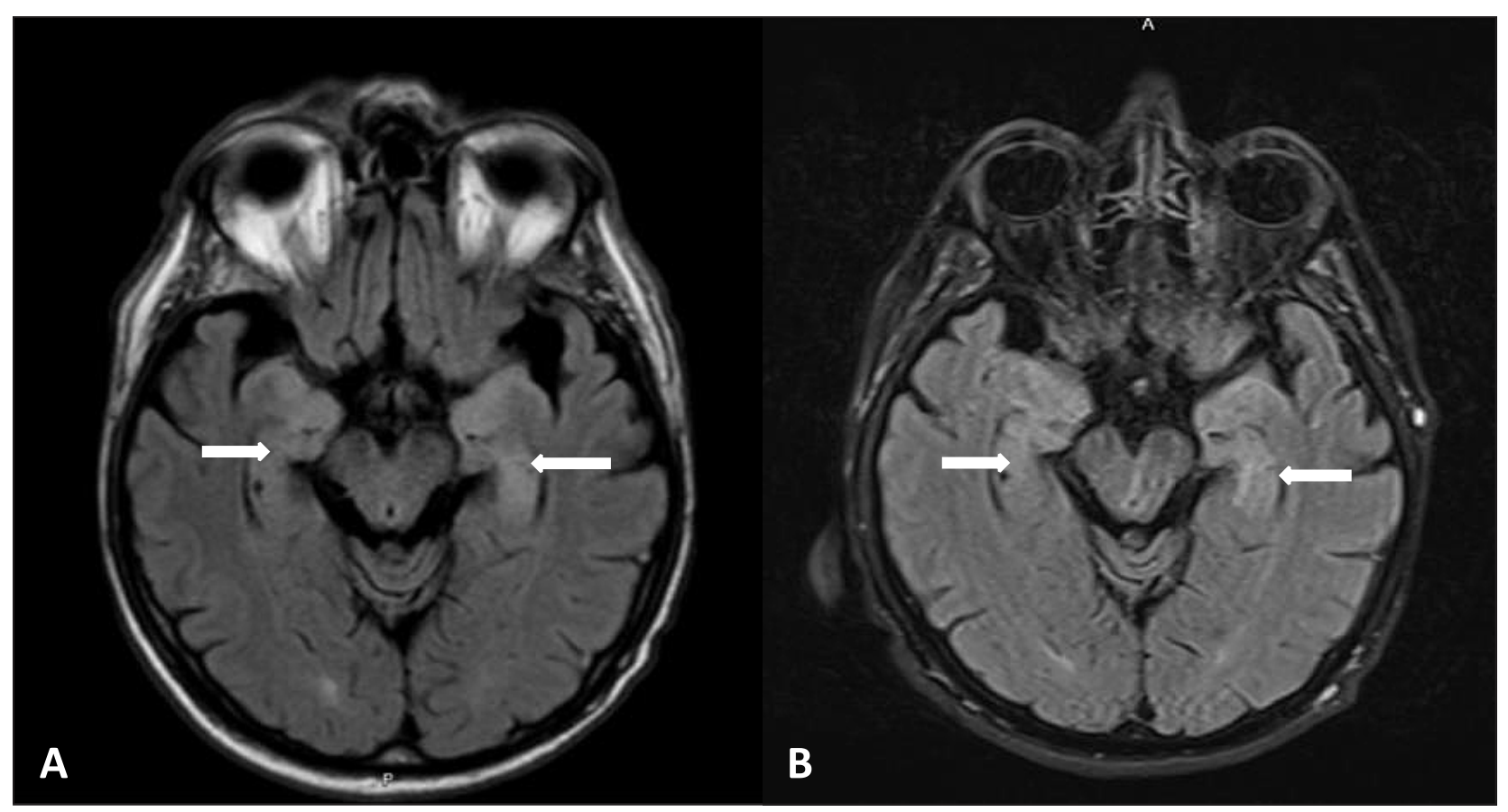

1 pav. Galvos smegenų magnetinio rezonanso tomografija.

A - T2 tamsaus skysčio seka, hiperintensinis signalas medialinėse smilkininių skilčių dalyse ir hipokampuose.

B - T2 tamsaus skysčio seka. Kontrolinis tyrimas po 6 mėnesių - išlieka signalo hiperintensyvumas.

\section{KLINIKINIS ATVEJIS}

Pacientas, 62 metų vyras, hospitalizuotas ị Nervų ligų skyrių dèl progresuojančio rankų ir kojų silpnumo, pamažu blogejjančios atminties, skonio ir kvapo jutimų sutrikimo, epilepsijos priepuolių ir krentančio svorio. Pacientas apie 40 metų rūkè cigaretes ir kelerius metus dirbo asfaltinių kelių tiesimo darbus. Lètinių ligų anksčiau nediagnozuota.

Pirmieji simptomai pasireiške prieš metus: atsirado kojų silpnumas po sunkesnio fizinio krūvio, galvos svaigimas, sutriko skonio ir kvapo jutimai. Atliktas galvos magnetinio rezonanso tomografijos (MRT) tyrimas, kurio vaizduose $\mathrm{T} 2$ ir tamsaus skysčio sekose buvo matomos hiperintensinès zonos abipus hipokampuose ir vidinėse smilkininių skilčių dalyse, be difuzijos restrikcijos (1A pav.). Kojų silpnumas toliau progresavo, atsirado rankų proksimalinių dalių silpnumas, todèl, praejus 2 mėnesiams nuo ligos simptomų pradžios, pacientas hospitalizuotas ị Nervų ligų skyrių. Stuburo kaklinės dalies MRT tyrimo metu C6/7 lygyje nustatyta $6 \mathrm{~mm}$ disko išvarža, kuri siaurino stuburo kanalą. Hospitalizavus taip pat stebèti priepuoliai, kuriu metu isitempdavo paciento rankos, jis skleisdavo neaiškius, gerklinius garsus, sutrikdavo sąmonè. Priepuolis tęsdavosi iki poros minučių. Elektroencefalografinio tyrimo metu kairèje frontalinèje skiltyje fiksuotos lètos $1 \mathrm{~Hz}$ dažnio bifazinès-polifazinès bangos ir keli panašaus pobūdžio bangų paroksizmai abipus smilkininèse ir kaktinėse derivacijose. Nustatyta kaklinès mielopatijos ir struktūrinès epilepsijos diagnozè ir pradètas gydymas karbamazepino tabletemis $200 \mathrm{mg} 3$ kartus per dieną. Priepuoliai liovèsi, tačiau, nutraukus vaisto vartojimą, vèl atsinaujino. Po mènesio atlikta stuburo kaklinès dalies dis- ko išvaržos pašalinimo operacija ( 2 pav.). Tačiau būklè vis blogèjo, galūnių silpnumas toliau progresavo, atsirado atminties, nuotaikos sutrikimų. Nustačius depresiją, pradètas gydymas escitalopramu $20 \mathrm{mg} 1$ kartą per dieną. $\mathrm{Pa}-$ cientas hospitalizuotas ị Vilniaus universiteto Santaros klinikų Nervų ligų skyrių.

Neurologinès apžiūros metu pacientas galëjo pats atsisèsti lovoje, tačiau be pagalbos nepaeidavo dèl proksimali-

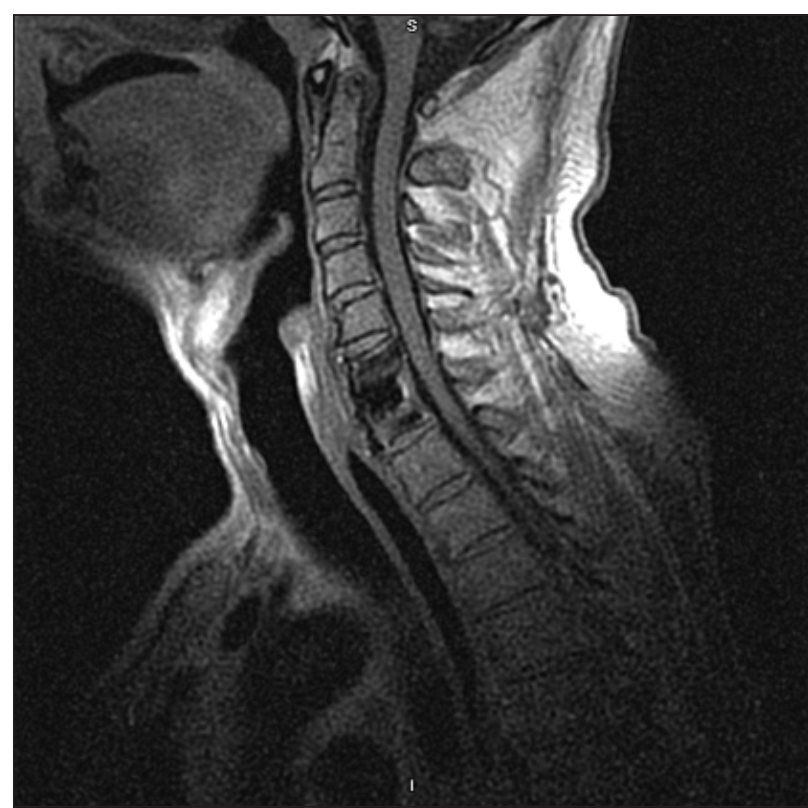

2 pav. Kaklo magnetinio rezonanso tomografija po išvaržos pašalinimo operacijos.

Stuburo kaklinės dalies MRT po išvaržos pašalinimo operacijos. Mielopatijos požymių nematyti. 
1 lentelè. Ritminė nervo stimuliacija su tetanizacija

\begin{tabular}{|c|c|c|c|c|c|c|}
\hline Nervas / raumuo & $\begin{array}{l}\text { Puse } \\
\text { D/K }\end{array}$ & \begin{tabular}{|c|} 
M atsako \\
amplitude \\
$\mathrm{mV}$
\end{tabular} & $\begin{array}{c}\text { Dekrementas } \\
\text { I serija } \\
\%\end{array}$ & $\begin{array}{c}\text { Dekrementas } \\
\text { IV serija } \\
\%\end{array}$ & $\begin{array}{c}\text { Dekrementas } \\
\text { po tetanizacijos } \\
\%\end{array}$ & $\begin{array}{c}\text { Dekrementas } 2 \text { min. } \\
\text { po tetanizacijos } \\
\%\end{array}$ \\
\hline N. accessorius / m. trapezius & $\mathrm{D}$ & 7,5 & 9,9 & 10,7 & 11,8 & 10,4 \\
\hline N. medianus / m. abductor pollicis brevis & $\mathrm{D}$ & 3,7 & 23,9 & 25,8 & $-27,1$ & 21,4 \\
\hline$N$. peroneus / $m$. tibialis anterior & $\mathrm{D}$ & 2,0 & 20,0 & & $-46,9$ & \\
\hline
\end{tabular}

Paaiškinimas. Ženklas „-“ reiškia atsako padidèjimą.

nių kojų raumenų silpnumo. Pacientas buvo orientuotas laike ir vietoje. Kalba ir psichomotorinè veikla - sulètinta, veidas - hipomimiškas. Raumenų jèga rankose, pagal Medicininių tyrimų tarnybos skalę (angl. Medical Research Council, MRC.): proksimaliai - 4 balai, distaliai - 4+ balai. Kairès kojos jèga - 3 balai, dešinès - 4 balai. Raumenys - hipotoniški. Sausgyslių refleksai rankose - simetriški, distaliai žemesni. Kojose neišgautas Achilo refleksas abipus. Patologinių refleksų negauta. Pacientas nurode dizesteziją abiejose kojose žemiau čiurnų. Krūvio mėginiai buvo neigiami. Ataksijos požymių ir meningito simptomų nebuvo nustatyta. Trumpasis protinès būklès klausimyno (angl. Mini-Mental State Examination, MMSE) įvertis siekè 21 balą. Vyravo trumpalaikès atminties ir dèmesio sutrikimai.

Atlikti bendrieji klinikiniai kraujo tyrimai, eritrocitu nusėdimo greitis, gliukozès, kalio, natrio ir chloro koncentracija kraujo serume, ištirti kepenų ir inkstų funkcijos rodikliai, tirotropino koncentracija kliniškai reikšmingų patologinių pakitimų neparodè. Antikūnų prieš ŽIV (žmo- gaus imunodeficito virusas) ir Laimo ligos sukèlejus neaptikta. Rasta nedaug padidinta kreatinkinazès koncentracija - 199 veikimo vienetai/l (norma - 25-195) ir sumažèjusi bendro baltymo koncentracija kraujyje - 62,6 g/l (norma 66-68). Atlikta juosmeninė punkcija. Bendras leukocitu skaičius smegenų skystyje buvo $8 \mu \mathrm{l}$, iš kurių $100 \%$ sudare monomorfonuklearai. Nustatyta nedaug padidinta baltymo koncentracija smegenų skystyje - 0,535 g/l (norma $0,15-0,45)$.

İtariant polineuropatiją, atliktas elektroneurografijos tyrimas, kurio metu rasta dešinės rankos motorinių ir sensorinių nervų aksonopatija ir mišraus tipo kojų nervų pažeidimas, vyraujant aksonopatijai. Ritminès nervo stimuliacijos metu stebėtas miastenijai būdingas $\mathrm{M}$ (suminis raumens veikimo potencialas) atsako amplitudès ir ploto dekrementas. Stimuliuojant $3 \mathrm{~Hz}$ dažniu, $\mathrm{M}$ atsako dekrementas siekè 23,9\% ir laipsniškai didejo, kartojant stimuliacijų serijas. Po tetanizacijos gautas didžiausias $\mathrm{M}$ atsako inkrementas - 46,9 \% (1 lentelè). Elektroencefalografi-

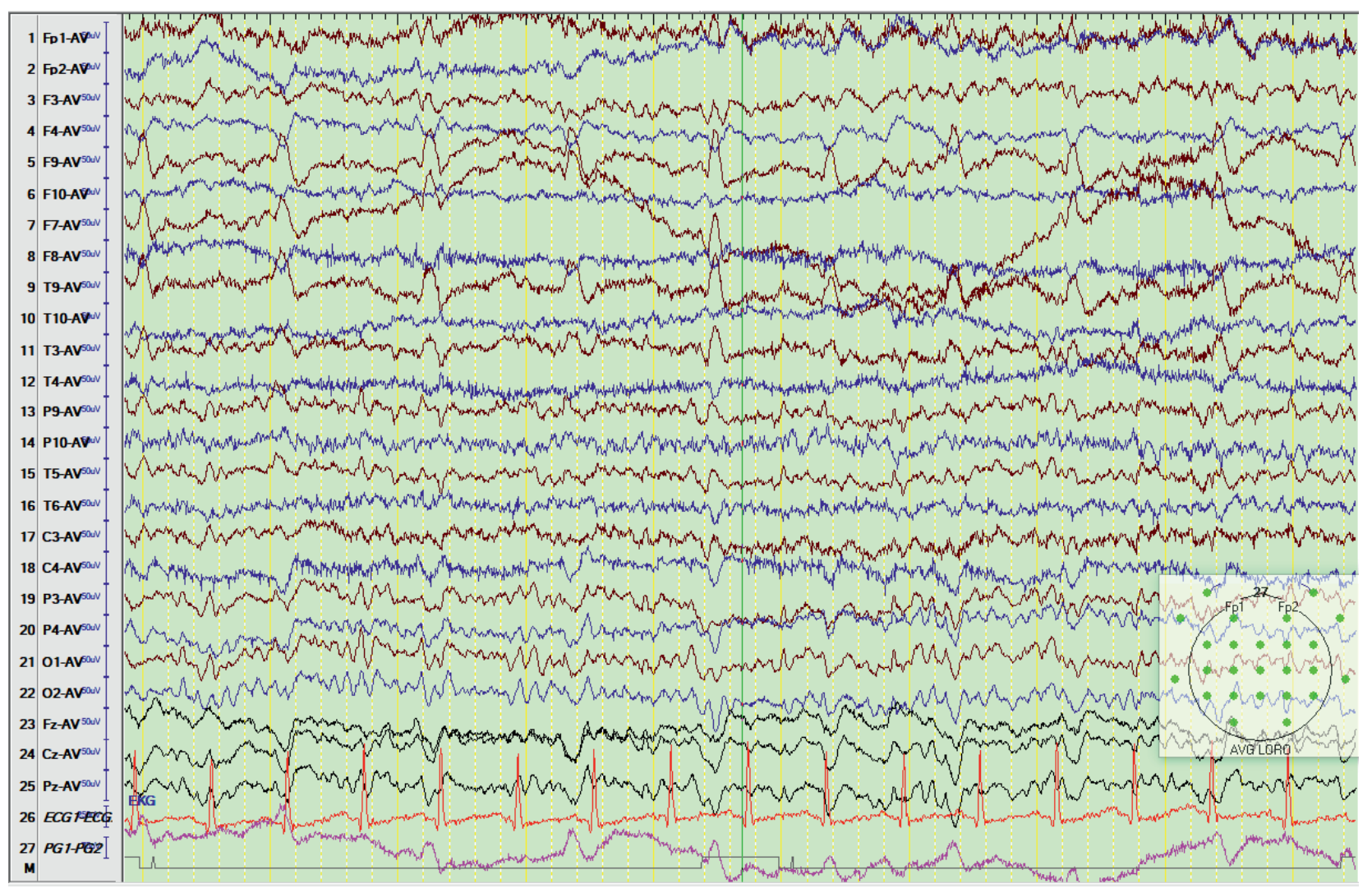

3 pav. Elektroencefalografijos tyrimas.

Patologinės polifazinės smailios bangos kairejje kaktinėje ir smilkininėje skiltyse, plintančios ị kairị pusrutuli 
jos tyrimo metu nustatytos patologinès polifazinès smailios bangos kaireje kaktinejje ir smilkininejje skiltyse, kurios plito ị visą kairị pusrutuli (3 pav.). Pakartotas galvos MRT tyrimas. Rasti patologiniai pakitimai temporalinèse skiltyse nesiskyrė lyginant su anksčiau atliktu tyrimu (1B pav.).

Taigi, ịvertinus klinikinio neurologinio ištyrimo ir paraklinikinių tyrimų rezultatus, nustatyti 3 skirtingi neurologiniai sindromai: limbinio encefalito (depresija, kognityvinis sutrikimas, epilepsija, patvirtinta pakitimais MRT tyrime ir EEG), sensomotorinès aksoninio tipo polineuropatijos (jutimų sutrikimai kojose distaliai, žemesni sausgyslių refleksai rankose ir išnykę Achilo sausgyslès refleksai, patvirtinta elektroneurografijos tyrimu) ir miasteninis sindromas (vyraujantis proksimalinis raumenų silpnumas, kurio nebuvo galima paaiškinti polineuropatija dèl jos santykinai nedidelio išreikštumo. Tačiau ritminès stimuliacijos metu nustatyti laidumo sutrikimai neuroraumenineje jungtyje buvo pakankami, siekiant patvirtinti miastenini sindromą kaip šio silpnumo priežasti).

Tokių poūmiai išsivysčiusių, progresuojančių neurologinių sindromų derinys leido ịtarti paraneoplazinį sindromą. Tirti onkoneuroninių antikūnų, taip pat antikūnų prieš neuronų paviršiaus antigenus ir acetilcholino receptorius titrai buvo neigiami (2 lentelè).

Nepaisant neigiamo imunologinio tyrimo rezultato, pradèta onkologinės ligos paieška. Atlikus pilvo organų echoskopiją, onkologinių pakitimų vidaus organuose ir pilvaplèvès ertmėje nebuvo nustatyta, rasti pilvo aortos ateroskleroziniai pakitimai su priesieniniais trombais. Plaučių rentgenograma taip pat buvo normali, tačiau, atlikus krūtinès ląstos kompiuterinę tomografiją su intraveniniu kontrastavimu, rastas $36 \times 38 \mathrm{~mm}$ dydžio, netolygiai kaupiantis kontrastą darinys užpakaliniame tarpuplautyje ir padidinti dešinès plaučių šaknies bei bifurkaciniai limf-

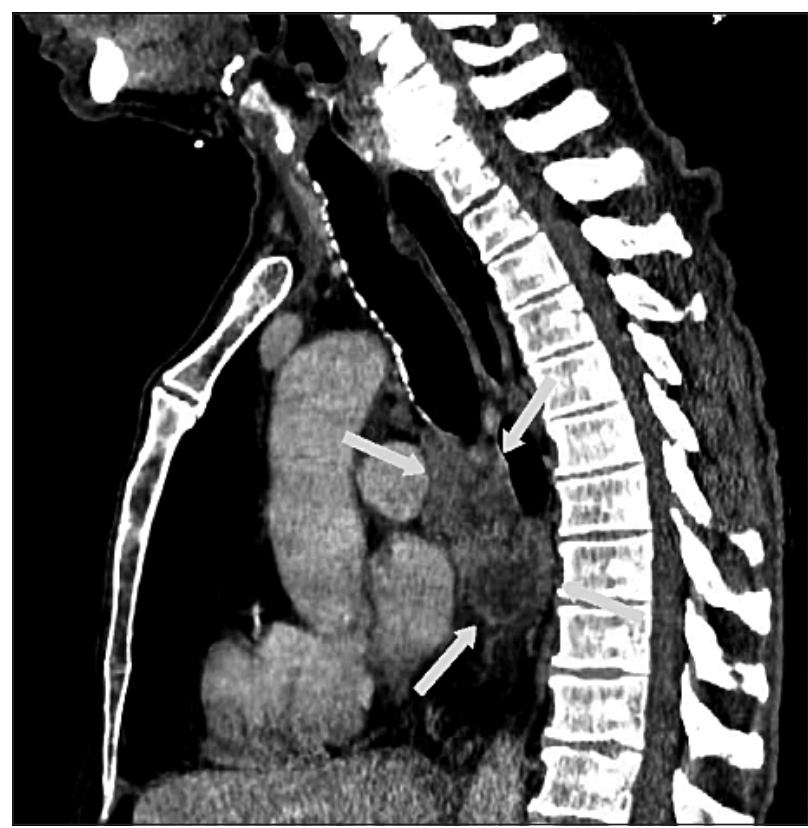

4 pav. Krūtinès ląstos KT rekonstrukcija. Darinys užpakaliniame tarpuplautyje
2 lentelè. Pacientui ištirti antineuroniniai antikūnai

\begin{tabular}{||l|l|}
\hline Antikūnai & Rezultatas \\
\hline Anti-amfifizinas & Neigiamas \\
\hline Anti-CV2 (CRMP-5) & Neigiamas \\
\hline Anti-PNMA (Ma2/Ta) & Neigiamas \\
\hline Anti-Ri (ANNA-2) & Neigiamas \\
\hline Anti-Yo (PCA-1) & Neigiamas \\
\hline Anti-Hu (ANNA-1) & Neigiamas \\
\hline Anti-NMDR & Neigiamas \\
\hline Anti-AMPAR1 & Neigiamas \\
\hline Anti-AMPAR2 & Neigiamas \\
\hline Anti-CASPR2 & Neigiamas \\
\hline Anti-LGI1 & Neigiamas \\
\hline Anti-GABAR (B1/B2) & Neigiamas \\
\hline Anti-AchR & Neigiamas \\
\hline \hline
\end{tabular}

Anti-Hu (ANNA-1) - I tipo antikūnai prieš neuronų branduolius, Anti-Ri (ANNA-2) - II tipo antikūnai prieš neuronų branduolius, Anti-Yo (PCA-1) - Purkinje ląstelių antikūnai 1, Anti-PNMA (Ma2/Ta) - paraneoplazinis Ma antigenas 2, Anti-CV2 (CRMP-5) - šoko mediatoriaus baltymas 5, Anti-NMDAR - N-metil-D-aspartato receptorius, Anti-LGI1 leucinų turtinga, inaktyvuota glioma 1, Anti-CASPR2 - su kontaktinu asocijuotas baltymas 2, Anti-AMPAR - $\alpha$-aminohidroksimetil-isoksazolio propioninès rūgšties receptorius, Anti-GABAR (B1/B2) - gama-amino sviesto rūgšties receptorius.

mazgiai (4 pav.). Tarpuplaučio darinio bioptato histologinio tyrimo metu nustatyta blogai diferencijuota (G3) neuroendokrininė smulkių ląstelių karcinoma.

Ivertinus visus turimus duomenis, suformuluota klinikinè diagnozė - smulkių ląstelių plaučių karcinoma: paraneoplazinis miasteninis sindromas, paraneoplazinis limbinis encefalitas ir sensomotorine polineuropatija.

Pacientas gydytas piridostigminu $60 \mathrm{mg} 4$ kartus per dieną, karbamazepinu 200 mg 3 kartus per dieną, prednizolonu $30 \mathrm{mg} 2$ kartus per dieną, escitalopramu $20 \mathrm{mg}$ 1 kartą per dieną, profilaktinėmis fraksiparino dozemis $0,3 \mathrm{ml} 2$ kartus per dieną. Atliktos 4 pakaitinès aferezès (iš viso pakeista 9,4 1 plazmos). Gastroprotekcijai skirtas omeprazolis $20 \mathrm{mg} 1$ kartą per dieną. Nei gydant vaistais, nei gydomosiomis aferezèmis, teigiamo klinikinio efekto nebuvo. Pacientas tolimesniam gydymui išsiųstas ị Nacionalinị vèžio institutą.

\section{APTARIMAS}

Remiantis literatūros duomenimis, net $80 \%$ atvejų PNS manifestuoja pirmiau nei onkologinė liga [7]. Dažniausiai nustatomi PNS, susiję su SLPK, yra: Lambert-Eaton miasteninis sindromas $-3,8 \%$, sensorinè neuronopatija - 1,9\% ir limbinis encefalitas - 1,5\% [1]. Remiantis M. Raspotnig ir bendraautorių publikuota 31 paciento su PNS analize, keli vienu metu pasireiškiantys PNS nėra retas reiškinys. 
Dažniausiai kartu su kitais PNS diagnozuojama sensomotorinė polineuropatija. Mūsų pacientui nustatyti du būdingi SLPK paraneoplaziniai susirgimai: sensomotorinė polineuropatija ir limbinis encefalitas. Tačiau labiausiai išreikštas klinikinis požymis buvo proksimalinių galūnių raumenų silpnumas, kurị lèmé neuroraumeninès jungties pažeidimas. Mūsų pacientui ritminès nervo stimuliacijos metu stebètas miastenijai būdingas $\mathrm{M}$ atsako amplitudès ir ploto dekrementas. Po tetanizacijos gautas inkrementas siekė 46,9\%. Žinoma, kad M atsako inkrementas po tetanizacijos būdingas presinapsinėms mioneuralinès jungties ligoms, pvz., Lambert-Eaton miasteniniam sindromui. Tačiau nedidelis inkrementas gali būti nustatomas ir miastenija sergantiems pacientams dẻl poaktivacinès potenciacijos fenomeno [8]. Lambert-Eaton miasteniniam sindromui būdingas inkrementas paprastai siekia daugiau nei $100 \%$ ir tik retais atvejais būna mažesnis. Kai kurių autorių nuomone, Lambert-Eaton miasteninị sindromą turètume įtarti tuomet, kai bent poros raumenų inkrementas yra didesnis nei 50 \% [9]. Taigi, mūsų paciento atveju elektrofiziologinių tyrimų radiniai daugiau būdingi miastenijai (posinapsiniam pažeidimui), nei presinapsinėms neuroraumeninès jungties ligoms.

Myasthenia gravis, susijusi su plaučių vėžiu, pasireiškia ypač retai. Publikuoti keli atvejai, kai onkologinis plaučių susirgimas nustatytas jau prieš tai daug metų miastenija sergantiems pacientams [10, 11]. Dar rečiau myasthenia gravis pasireiškia kartu su plaučių vėžiu. Tuomet šis susirgimas traktuojamas kaip galimas PNS [10, 12-14]. Visgi myasthenia gravis, kaip plaučių vėžio sukeltas PNS, iki šiol dar nèra oficialiai patvirtinta ir remiasi tik kelių klinikinių atvejų aprašymais [10, 12-14].

Onkoneuroninių antikūnų nustatymas kartu su jiems būdingu neurologiniu sindromu yra labai specifiški PNS radiniai [5]. Mūsų pacientui tiek onkoneuroninių, tiek dažniausių antikūnų prieš neuronų paviršiaus antigenus titrai buvo neigiami. Miastenijai būdingų antikūnų prieš acetilcholino receptorius taip pat neaptikome. Tai galejjo lemti per siauras tirtų antineuroninių antikūnų spektras. Beje, kitų su miastenija asocijuotų antikūnų: antikūnų prieš skersaruožius raumenis (angl. anti-SM, anti-striated muscle), raumenims specifinès kinazès antikūnų (angl. anti-MuSK, anti-muscle-specific kinase), su 4-uoju lipoproteinu asocijuoto baltymo antikūnų (angl. anti-LRP4, anti-lipoprotein-related protein 4) ir antikūnų prieš įtampos valdomus kalcio kanalus (angl. anti-VGCC, anti-voltage-gated calcium channels), būdingų Lambert-Eaton miasteniniam sindromui, ištirti neturejome galimybès. Remiantis atliktų tyrimų duomenimis, 20-50 \% pacientų, kuriems diagnozuotas PNS, onkoneuroninių antikūnų neaptinkama [5, 15, 16]. Nustatyta, kad $14 \%$ atvejų, kai serumo antineuroninių antikūnų tyrimas buvo neigiamas, tiriant smegenų skystị aptinkama antineuroninių antikūnų [17]. Manoma, kad ateityje seronegatyvių pacientų skaičius mažès, nes atrandama vis daugiau naujų su PNS asocijuotų antikūnų [5].

PNS gydyti dažniausiai taikomas imunomoduliuojantis gydymas gliukokortikoidais, intraveniniais imunoglo- bulinais, plazmaferezėmis, tačiau šie gydymo metodai retai būna efektyvūs. Manoma, kad tai susiję su negrižtamu imuniniu neuronų pažeidimu [15]. Geriausias būdas stabilizuoti PNS - ankstyva onkologinio proceso diagnostika ir gydymas [15].

\section{IŠVADOS}

PNS yra reta ir diagnostiškai paini nervų sistemos patologija. Nors ir nėra oficialiai pripažinta, tačiau myasthenia gravis, kaip PNS pasireiškimas, galètų būti susijusi su smulkių ląstelių plaučių karcinoma. Kito mūsų paciento miasteninio sindromo etiologijos paaiškinti negalèjome. Svarbu paminèti, kad imunomoduliuojantis PNS gydymas, kuris plačiai taikomas pasaulyje, retai būna efektyvus. Ankstyva tiek onkologinio proceso, tiek PNS diagnostika ir gydymas gali sumažinti paciento negalią ir pagerinti išeitis [15].

\section{Literatūra}

1. Gozzard P, Woodhall M, Chapman C, et al. Paraneoplastic neurologic disorders in small cell lung carcinoma: A prospective study. Neurology 2015; 85(3): 235-9. https://doi.org/10.1212/WNL.0000000000001721

2. Dalmau J, Rosenfeld MR. Paraneoplastic syndromes of the CNS. Lancet Neurol 2008; 7(4): 327-40. https://doi.org/ 10.1016/S1474-4422(08)70060-7

3. Dalmau J, Gultekin HS, Posner JB. Paraneoplastic neurologic syndromes: pathogenesis and physiopathology. Brain Pathol 1999; 9: 275-84. https://doi.org/10.1111/ j.1750-3639.1999.tb00226.x

4. Voltz R. Paraneoplastic neurological syndromes: an update on diagnosis, pathogenesis, and therapy. Lancet Neurol 2002; 1(5): 294-305. https://doi.org/10.1016/ S1474-4422(02)00135-7

5. Leypoldt F, Wandinger KP. Paraneoplastic neurological syndromes. Clin Exp Immunol 2014; 175: 336-48. https://doi.org/10.1111/cei.12185

6. Lancaster E, Dalmau J. Neuronal autoantigens pathogenesis, associated disorders and antibody testing. Nat Rev Neurol 2012; 8: 380-90. https://doi.org/10.1038/ nrneurol.2012.99

7. Raspotnig M, Vedeler C, Storstein A. Paraneoplastic neurological syndromes in lung cancer patients with or without onconeural antibodies. J Neurol Sci 2015; 348(1-2): 41-5. https://doi.org/10.1016/j.jns.2014.10.040

8. Cherian A, Baheti NN, Iype T. Electrophysiological study in neuromuscular junction disorders. Ann Indian Acad Neurol 2013; 16: 34-41. https://doi.org/10.4103/0972-2327.107690

9. Titulaer MJ, Lang B, Verschuuren JJGM. Lambert-Eaton myasthenic syndrome: from clinical characteristics to therapeutic strategies. Lancet Neurol 2011; 10: 1098-107. https://doi.org/10.1016/S1474-4422(11)70245-9

10. Shaygannejada V, Ghasemi M, Rajaee Z. Myasthenia gravis as a presenting feature in a patient with lung cancer: A case report. J Res Med Sci 2011; 16(2): 229-32.

11. Sakamaki Y, Yoon HE, Oda N. Non-small-cell lung cancer associated with non-thymomatous myasthenia gravis. 
Jpn J Thorac Cardiovasc Surg 2006; 54(5): 207-11. https://doi.org/10.1007/BF02670314

12. Peltier AC, Black BK, Raj SR, et al. Coexistent autoimmune autonomic ganglionopathy and myasthenia gravis associated with non-small-cell lung cancer. Muscle Nerve 2010; 41: 416-9. https://doi.org/10.1002/mus.21528

13. Eivaz-Mohammadi S, Gonzalez-Ibarra F, Hekmatjou H, et al. Myasthenia gravis-like syndrome presenting as a component of the paraneoplastic syndrome of lung adenocarcinoma in a nonsmoker. Case Reports in Oncological Medicine 2014; 2014: 703828. https://doi.org/10.1155/2014/703828

14. Kataoka K, Fujiwara T, Matsuura M, et al. A case of simultaneously operated primary multiple lung cancers with non-thymomatous myasthenia gravis. Japanese Journal of Lung Cancer 2009; 49(3): 273-7. https://doi.org/10.2482/ haigan. 49.273

15. Honnorat J, Antoine JC. Paraneoplastic neurological syndromes. Orphanet J Rare Dis 2007; 2: 22. https://doi.org/ 10.1186/1750-1172-2-22

16. Zoccarato M, Gastaldi M, Zuliani L, et al. Diagnostics of paraneoplastic neurological syndromes. Neurol Sci 2017; 38: 237-42. https://doi.org/10.1007/s10072-017-3031-5

17. Zuliani L, Zoccarato M, Gastaldi M, et al. Diagnostics of autoimmune encephalitis associated with antibodies against neuronal surface antigens. Neurol Sci 2017; 38: 225-9. https://doi.org/10.1007/s10072-017-3032-4
R. Bunevičiūtė, R. Masaitienė, A. Klimašauskienė

MYASTHENIA GRAVIS AS ONE

OF PARANEOPLASTIC NEUROLOGICAL SYNDROMES ASSOCIATED WITH SMALL CELL LUNG CANCER. CASE REPORT

\section{Summary}

Myasthenia gravis associated with extrathymic malignancies is a rarely diagnosed pathology in clinical practice. We report a case of myasthenia gravis-like syndrome associated with small cell lung cancer. A male patient has been diagnosed with 3 different paraneoplastic neurological syndromes: sensorimotor polyneuropathy, limbic encephalitis and myasthenia gravis-like syndrome which was confirmed by positive repetitive nerve stimulation test.

The causal association between small cell lung cancer and myasthenia gravis as a paraneoplastic neurological syndrome (PNS) has not been officially confirmed yet. However, there is increasing evidence in the literature, that myasthenia gravis could be one of the PNS phenotypes of non-thymomatous malignancies.

Keywords: paraneoplastic syndrome, myasthenic syndrome, lung carcinoma

Gauta:

Priimta spaudai:

20180102 